\title{
Исламское государство входит в старую теплицу Аль-Каиды: Афганистан и Пакистан
}

\section{Мона Канвал Шейх}

Датский институт международных исследований, http://www.diis.dk

\begin{abstract}
Резюме: Движение Исламское государство создало новое подразделение в районе Афпака, изменяя таким образом ландшафт вооруженных движений в этом регионе. В этой статье рассматриваются схемы соперничества и сотрудничества между Исламским государством, с одной стороны, и связанными с Аль-Каидой и Талибаном движениями, с другой. Сделан также обзор развития Аль-Каиды в последние годы, когда международное внимание было, в основном, направлено на формирование ИГ в Ираке/Сирии, и показано, что Аль-Каида все еще активна, хотя она стала более локально ориентированной. И наконец, в статье рассматриваются перспективы дальнейшей экспансии ИГ, конкретнее в Пакистан, где, с одной стороны, ряд сектантских антишиитских движений реагируют положительно на некоторые части повестки дня ИГ и, с другой стороны, нет идеологической традиции приверженности к тому халифатскому джихадизму, который проповедует ИГ.
\end{abstract}

Ключевые слова: джихадизм, Исламское государство Хорасан, АльКаида, Талибан, Афганистан, Пакистан, терроризм.

\section{Введение}

Десять лет назад граничные области между Пакистаном и Афганистаном были командным пунктом для лидеров Аль-Каиды (АК). Но что происходит с Аль-Каидой с тех пор? И какие виды сотрудничества или конфликтов существуют там между доминирующим в регионе движением, связанным с Талибаном, АК, и новым игроком - Исламским государством? Далее я рассматриваю появление ИГ в Афганистане и Пакистане и динамику, которая оказывала влияние на отношения между «старыми» движениями в этом 
регионе (Талибан и АК), с одной стороны, и ИГ, с другой. ИГ является все еще развивающимся движением в регионе Афпака, и поэтому нет еще четкой картины его влияния и восприятия в Афганистане и в Пакистане. Поскольку ситуация все еще находится в развитии, данная статья основывается на материалах очень ограниченного перечня источников об этом движении. ${ }^{1}$

\section{Исламское государство Хорасан}

В начале 2015 года Исламское государство открыло новый филиал, функционирующий в Афганистане и Пакистане. Учреждение нового афгано-пакистанского подразделения ИГ было объявлено его главным представителем, Абу Мухаммад аль-Аднани, из одной из штаб-квартир ИГ в Сирии. В почти семиминутной речи аль-Аднани объявил, что группировка расширится чем-то, что он назвал «Хорасан ». ${ }^{2}$ Поэтому эта часть группировки далее называется "ИГХ» (Исламское государство Хорасан). Речь была опубликована 26 января 2015 года в Аль-Фуркан, медиа бюро ИГ. Объявление появилось несколько недель после того, как группа бывших приверженцев движения «Талибан» в Пакистане создали так называемый «Хорасанский совет» (шура) и публично заявили о своей лояльности ИГ.

Поэтому афгано-пакистанская фракция тесно связана с движением ИГ, которое появилось в Ираке в 2013 году. Руководство ИГХ заявило о своей лояльности (баях) Абу Бакр аль-Багдади, самопровозглашенному халифу, появление которого стало неожиданностью для всего мира, когда он произнес речь о своей миссии в мечети в Мосуле в июле 2014 года. Хотя ИГХ имеет только ограниченное присутствие в Пакистане, сегодня оно присутствует в приблизительно семи афганских провинциях, в основном в восточной части провинции Кунар и в соседней провинции Нангархар. ИГ бросило вызов афганскому Талибану в обеих частях Нангрхара, Херате и

1 В существующей литературе по ИГ в основном рассматривается появление ИГ в Ираке и его расширение в Сирию. Есть множество доктринальных работ и отчетов по этой теме (в том числе публикации институтов Брукингс, Карнеги, Международной кризисной группы и ДИМИ). В число книг, рассматривающих восход ИГ входят, например, Jessica Stern and J.M. Berger, ISIS: The State of Terror (New York: HarperCollins, 2015); Charles R. Lister, The Islamic State: A Brief Introduction (Washington, D.C.: Brookings, 2015); Patrick Cockburn, The Rise of Islamic State: ISIS and the New Sunni Revolution (London: Verso, 2015); Abdel Bari Atwan, Islamic State - the Digital Caliphate (London: Saqi Books, 2015); William McCants, The ISIS Apocalypse: The History, Strategy, and Doomsday Vision of the Islamic State (Washington, D.C.: Brookings, 2015).

2 Декларация, опубликованная 26 января 2014 года Аль-Фуркан, медиа агентством ИГ, появилась всего несколько недель после того, как группа бывших представителей ТТП учредила шуру и объявила о своей верности аль-Багдади. 
Хелманде, но Восточный Нангархар стал наиболее прочной основой присутствия ИГ в Афганистане. ${ }^{3}$ (Фиг. 1).

Движение дало почувствовать свое присутствие, взяв на себя ответственность за самоубийственные нападения, вооруженные операции и похищения, в частности, в юго-восточном Афганистане, где ИГХ неуспешно пыталось оккупировать определенные территории, но так же и в северовосточном Афганистане, где движение было более успешным. ИГХ также наносило вред пакистанским интересам в Афганистане, в том числе напав на пакистанское консульство в Джелалабаде, столице Нангархара. ИГХ так же действовало в Пакистане, в частности совершая нападения в провинции Синдх, и по сообщениям в пакистанских новостях ИГХ успело приобрести приверженцев в племенных территориях Пакистана (ФУПТ), где пакистанский Талибан все еще имеет свои опорные пункты и где Аль-Каида раньше пользовалась широкой популярностью и защитой.

В списке террористических организаций США новый филиал ИГ называется ИГИЛ-Х (Исламское государство Ирака и Леванта - Хорасан), ${ }^{4}$ тогда, как они сами себя называют Вилаят Хорасан. Вилаят означает независимая административная единица, существовавшая при исторической системе халифата, и поэтому иногда это имя переводится как «провинция Хорасан». Следовательно, афганско-пакистанская фракция рассматривает себя как административную и военную единица глобального исламского халифата, создание которого стало целью движения ИГ в 2013 году, когда они расширили свою деятельность в Ираке, включив в нее Сирию.

Согласно некоторым докладам Военной академии Соединенных Штатов в Вест Пойнте, афгано-пакистанская фракция движения начала формироваться в начале 2014 года, ${ }^{5}$ когда бывшие приверженцы Аль-Каиды в Афганистане и Пакистане приняли идею, что иракец Абу Бакр аль-Багдади является халифом, который объединит мусульманский мир перед тем, как разверзнется окончательный апокалипсис.

Следует обратить внимание на то, что хотя его называют «провинцией», Хорасан не является территорией. Более оправдано рассматривать его в качестве движения в Афганистане и Пакистане, которое пытается осуществить видение ИГ об исламском халифате. Хорасан не существует больше в качестве провинции, но это наименование относится к историческому

3 Vanda Felbab-Brown, Blood and Faith in Afghanistan (Washington, D.C.: Brookings, 2016), доступно на www.brookings.edu/research/blood-and-faith-in-afghanistan-ajune-2016-update.

4 Bureau of Public Affairs Department of State. The Office of Website Management, "Designations of Foreign Terrorist Fighters," Press Release| Media Note, U.S. Department of State, September 29, 2015, доступно на www.state.gov/r/pa/prs/ps/2015/ 09/247433.htm.

5 Don Rassler, "Situating the Emergence of the Islamic State of Khorasan," CTC Sentinel 8, no. 3 (March 2015): 7-11, доступно на www.ctc.usma.edu/posts/situating-theemergence-of-the-islamic-state-of-khorasan. 


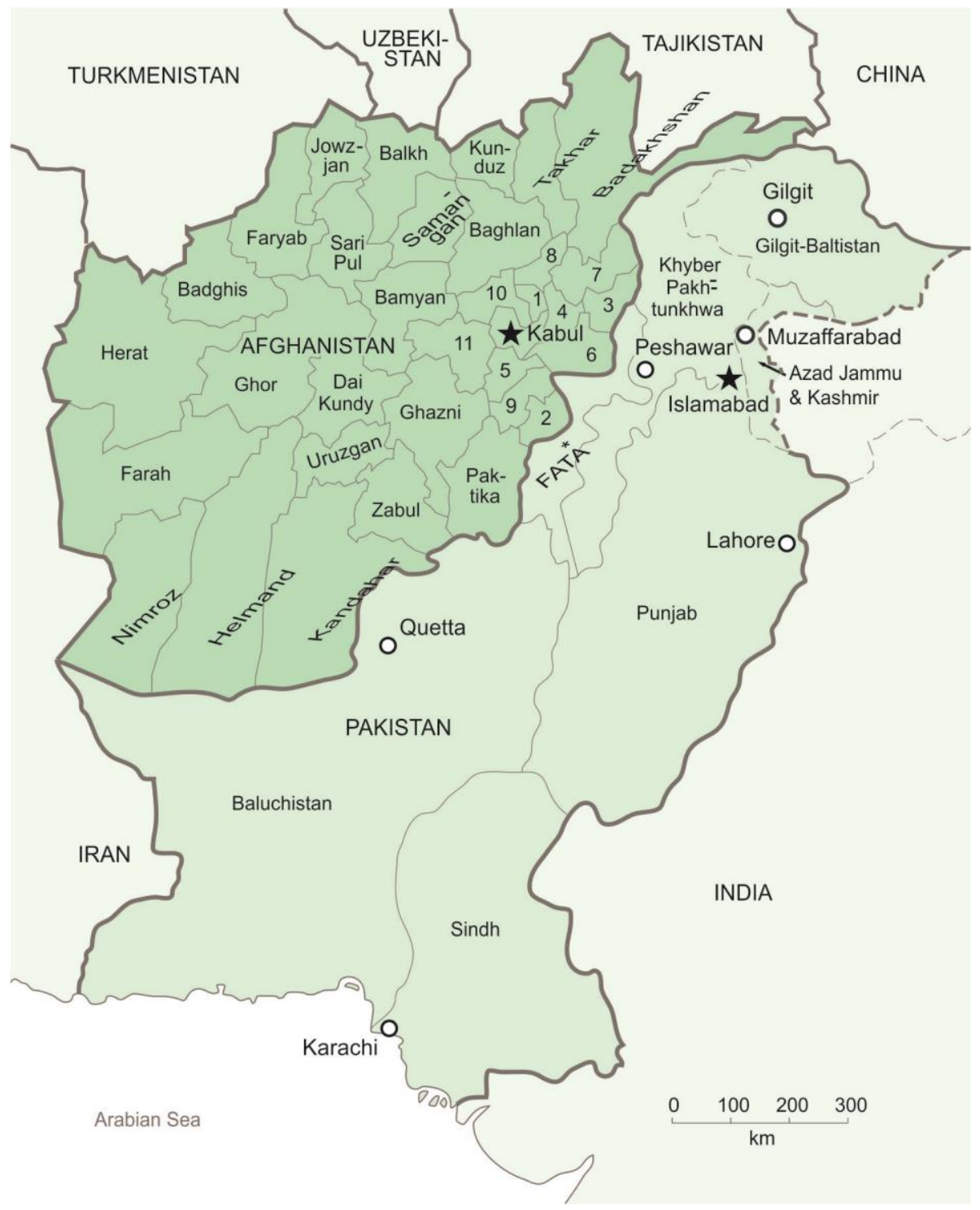

Фигура 1: Карта Афганистана и Пакистана.

региону, который охватывает части Афганистана, Туркменистана, Таджикистана, Узбекистана и большую часть Ирана. По некоторым описаниям, в эту историческую область включаются и части Пакистана. Согласно легендам, Хорасан является ключевым элементом эсхатологических рассказов о последних днях перед Судным днем. К примеру, в одном хадисе [писание о словах, действиях или обычаях пророка Мухаммеда], который использо- 
вался для утверждения легитимности движения ИГ, предсказывается, что в районе Хорасана поднимется армия, которая будет нести черные знамена. Мусульманский мессия (известный в эсхатологии как имам Мехди) выступит во главе этой армии и поведет мусульман к окончательной победе над врагами ислама, заново утвердив, таким образом, славу ислама. Один из параграфов этого хадиса призывает мусульман присоединиться к «армии черного флага», когда она появится. Легенду о Хорасане в качестве области, в которой произойдут решающие события, можно встретить и среди приверженцев движения Талибан, хотя они не признают ИГ движением, которое поведет весь ислам к окончательной победе.

Опорные пункты ИГХ в Афганистане находятся в провинции Кунар на северо-востоке Афганистана и в прилегающей провинции Нангархар (особенно в районе Ачин). Обе эти области граничат с племенными территориями в Пакистане (ФУПТ - Федерально Управляемые Племенные Территории, фиг. 1). Есть сведения, что ИГХ пыталось оккупировать южные провинции Фарах, Хелманд и Забул, но безуспешно. ${ }^{6}$ В число боевиков ИГХ входят афганцы, пакистанцы и узбеки из ИДУ (Исламское движение Узбекистана), которые до этого сотрудничали с Аль-Каидой и Талибаном. Доклад ООН от 2015 года описывает как ИДХ захватило части провинции Нангархар, принудительно закрыло 25 школ, запугав учителей и родителей (предположительно здания школ были заняты для организации военной деятельности).

ИГХ является слишком новым движением для того, чтобы с уверенностью сказать что-либо о его характере и структуре. Однако сведения журналистов и репортажи новостей дают нам некоторое представление об этом движении, которое часто воспринимается как «превосходящее» АК по методам и зрелищному применению насилия.

\section{Переезд ИГ в Пакистан}

В 2015 году стало ясно, что ИГХ медленно пробирается на пакистанскую «сцену джихада», частично из-за того, что ведущие члены разных пакистанских вооруженных движений объявили о своей преданности ИГ и альБагдади и потому, что в Пакистане стали наблюдать случаи пропаганды ИГ. Были сообщения о флагах ИГ и о про-ИГ граффити на стенах в Карачи и в Пешаваре - оба эти города раньше были опорными пунктами для сторонников Аль-Каиды и приверженцев Талибана. В конце 2015 года появились сообщения о распространении пропагандистских видеозаписей ИГ в Афганистане и Пакистане и о создании радиостанции «Голос Халифата» (с программами на арабском, пушту, фарси и дари), хотя она быстро была закрыта после воздушных ударов США по студии радиостанции. ${ }^{7}$

6 Franz J. Marty, "On the Trail of the Islamic State in Afghanistan," Foreign Policy, April 5, 2016, https://foreignpolicy.com/2016/04/05/afghanistan-islamic-state-taliban/.

7 Там же. 
В мае 2015 года была установлена связь нападения, повлекшего за собой смерть 46 мусульман-шиитов, со связанным с ИГ движением в Карачи, в провинции Синдх. Джундуллах - группировка, которая присягнула на верность ИГ в ноябре 2014 года - взяла на себя ответственность за это сектантское нападение. До этого Джундуллах было связано с пакистанской ветвью Талибана, но в идеологическом плане она ближе к ИГ и его миссии восстановления транснационального халифата.

Тоже в 2015 году были арестованы 42 человека в Сиалкоте (провинция Пенджаб) за то, что они предположительно являлись членами ячейки ИГ. В пакистанской столице Исламабад был арестован подозреваемый пакистанский лидер ИГ и ему были предъявлены обвинения в вербовке членов движения. Пакистанские СМИ сообщили, что в результате ареста стало известно, что ИГ платит новым рекрутам месячную зарплату в 380 долларов США, если они присоединятся к ИГ. Другие источники называли более высокую сумму, но как бы там не было, зарплата способствовала расширению присутствия ИГ в Пакистане, особенно в племенных территориях, где тысячи молодых мужчин и женщин ведут тяжелую жизнь без работы и в плохих социально-экономических условиях. ${ }^{9}$

Англоязычный журнал ИГ, Дабик, недавно опубликовал интервью с "губернатором (вали) Хорасана», в котором он говорит, что сейчас Хорасан охватывает Афганистан и западный Пакистан, и что у ИГ есть намерение перейти и в Кашмир (спорная территория между Пакистаном и Индией). Что касается их опоры в регионе, он сказал: «Мы создали суды в этих регионах, отделения хисбах [силы религиозной полиции], отделы для заках [благотворительности/раздачи милостыни] и другие для образования, давах [обращения в свою веру] и масаджид [мечети], и для публичных услуг». ${ }^{10}$ Однако, деятельности о которых он говорил, в большей степени относятся к Афганистану, чем к Пакистану, откуда приходят только отрывочные сообщения о создании связанными с ИГ шариатских судов или других типов параллельной администрации.

Зонтичная организация для Талибана в Пакистане, Техрик-е Талибан Пакистан (ТТП) состоит из целых движений, которые присоединились к ТТП, а также охватывает небольшие группы, отделившиеся от других движений, и ИГХ в Пакистане следует подобной схеме. Как было упомянуто выше, одно из движений, которые публично заявили о своей преданности ИГХ - это антишиитское движение Джундуллах. Движение Джундуллах согласно с желчным портретом шиитов, который рисует ИГ как «вероотступников» (рафидах), и заявляет, что мусульмане-шииты не признают преемников Пророка, Абу Бакра и Умара, в качестве законных халифов, утвер-

8 Farhan Zahid, "Growing Evidence of Islamic State in Pakistan," Terrorism Monitor 14, no. 3 (February 2016): 3-5, доступно на www.jamestown.org/programs/tm/single/ ?tx_ttnews\%5Btt_news\%5D=45065\&cHash=547a6e0e90327659248b7108b3925ab0.

9 Marty, "On the Trail of the Islamic State in Afghanistan."

10 "Interview with the Wali of Khurasan," Dabiq 13, стр. 48-58, цитата на стр. 49. 
ждая, что они не просто дезертиры, но и являются серьезной идеологической угрозой для истинного ислама и потому должны быть уничтожены. Джундуллах началось как движение сосланных иранских мусульман-суннитов, которые хотели свергнуть шиитский режим в Иране и со временем оно во все большей степени направляло свои усилия на борьбу с «отступниками» в Пакистане.

Как было упомянуто выше, другим движением, которое вошло в союз с ИГХ, является Исламское движение Узбекистана (ИДУ). ${ }^{11}$ Многие годы со времени своего изгнания в Пакистан и Афганистан ИДУ стремилось к созданию исламского государства в Узбекистане и сотрудничало с АК. Весьма вероятно, что ИГ считает союз с вооруженным ИДУ исключительно ценным, поскольку, по крайней мере на бумаге, Иг намеревается завладеть историческим Хорасаном (большая часть которого находится в Средней Азии) и, таким образом, исполнить предсказание хадиса, на который они ссылаются в своей пропаганде и в отношениях с другими движениями, которые включились в их борьбу. В ноябре 2015 года, однако, ИДУ было ослаблено в результате столкновения с афганским Талибаном и подверглось еще большей фрагментации, когда в июне 2016 небольшая группа из ИДУ повергла сомнению целесообразность верности своего бывшего руководителя ИГ и заявила о лояльности Аль-Каиде. Предварительные доклады показывают, что движение ИГХ так же привлекло в свои ряды боевиков, которые воевали для таких более локально базированных пакистанских движений, как Сипах-е-Сихаба и Лашкар-е-Джангви. Обе эти группировки хорошо известны своими антишиитскими настроениями и в течение многих лет они стояли за многими вооруженными нападениями на мусульман-шиитов в разных частях Пакистана. В некоторых случаях боевики ИГХ были верны двум господам, что означало, что они не обязательно рвали связи с движением, из которого они приходили, а просто присоединялись к идее, которой они больше всего сочувствовали на данный момент.

В число других движений, которые столкнулись с переходом своих членов в ряды ИГХ, входят Лашкар-е-Тайба (ЛеТ), Танзим нифаз-е-шариат Мухаммади (ТНШМ) и ТТП. Несмотря на «перебегание» членов, эти три движения сохраняют свою целостность и работают для достижения своих собственных целей. Сотрудничество между некоторыми частями ЛеТ и ИГХ, в частности, основано на личных отношениях между лидерами ИГ и лидерами ЛеТ в племенных территориях Пакистана. Могут быть стратегические и лично-дружественные причины для временного сотрудничества, выражающегося в том, что движения защищают друг друга или предоставляют друг другу логистическую поддержку, но полное включение ЛеТ в ИГХ трудно себе представить, поскольку основной целью борьбы ЛеТ всегда

11 Merhat Sharipzhan, "IMU Declares It Is Now Part of the Islamic State," Radio Free Europe/Radio Liberty, August 6, 2015, http://www.rferl.org/content/imu-islamicstate/27174567.html. 
был Кашмир, и вся их деятельность всегда была направлена против их архи-врага: Индии. ТТП было основано в 2007 году, однако, ЛеТ раскололось и небольшая его часть присоединилась к ТТП в племенных территориях Пакистана, таким образом отвернувшись от прежних связей с пакистанской армией. Однако, надо отметить, что для движения ЛеТ никогда движущей силой не была идея создания исламского халифата, да и вне своей военной деятельности, это миссионерское движение, направленное на распространение ислама через правильное по их представлениям исламское образование и воспитание. Другими словами, они верят в исламизацию снизу вверх, и в отличие от других исламских движениях в Пакистане, его голос никогда не звучал громко в дискурсах об учреждении исламского государства в Пакистане. Кроме того, у ЛеТ архи-националистический этос (выражающийся в его оппозиции к индийской идентичности), и целью его военных действий всегда была граница между Индией и Пакистаном, что трудно совместить с транснациональным проектом ИГ о халифате.

С другой стороны, ТНШМ было создано для исламизации пакистанского государства. С 2007 года ТНШМ в первую очередь ассоциируется с движением Талибан, но хотя они боролись за исламское государство в качестве национального проекта, идея исламского халифата не полностью чужда ТНШМ и можно допустить, что для определенных частей этого движения может быть привлекательна идея ИГ, что грядет апокалипсис. Как движение, ТНШМ пока не присягнуло на верность аль-Багдади и только отдельные его члены присоединились к ИГХ.

Бывшие приверженцы ТТП, которые присоединились к ИГХ, сделали это из-за своего недовольства образом, которым развивался Талибан в Пакистане. Некоторые говорят, что это является отражением кризиса в руководстве, который разразился в Талибане, когда лидер ТТП, Хакимулла Мехсуд, был уничтожен американцами в 2013 году. Главные приверженцы ТТП, в особенности первые его сторонники в племенных территориях, никогда не смирились с назначением Муллы Фаззулла (у которого не было никаких связей с племенными территориями) в качестве преемника Хакимуллы Мехсуда, который был не просто главой Талибана в Пакистане, но и могущественным племенным лидером. Поэтому бывшим членам ТTП, которые присоединились к ИГХ, не хватало лидера, которому они бы доверяли. Более того, в Талибане были разногласия по вопросу, заключать ли мирные соглашения с пакистанским государством, или такое действие было символическим пактом с системой неправоверных. Фрагментация движения пакистанского Талибана так же означала, что некоторые из боевиков в движении потеряли иллюзии о потенциале движения, и весьма вероятно, увидели в ИГ сильную альтернативу. 


\section{Есть ли место для ИГ?}

Отношения между ТТП в Пакистане и Талибаном в Афганистане, с одной стороны, и ИГ, с другой, скорее характеризуются напряжением и внутренней борьбой за власть, чем сотрудничеством и интеграцией. Другими словами, как обстоят дела на настоящий момент, движения ИГ и Талибан нельзя рассматривать как объединенные или стремящиеся к объединению, а как соперничающие движения, которые ослабляют друг друга, воюя друг против друга.

Летом 2015 года распространились вести о смерти Муллы Омара. Мулла Омар был объединяющей силой для движений пакистанского и афганского Талибана, которые присягнули на верность ему. Хотя, как и Мулла Омар, аль-Багдади носит титул «Эмир ул Моминин» (повелитель правоверных), Мулла Омар никогда не притязал на статус халифа, придерживаясь позиции, что Талибан остается национальным проектом. Поэтому, приверженцы движения Талибан не признали автоматически аль-Багдади или легитимность транснационального проекта халифата и во многих случаях имели место высказывания, в которых Талибы умаляли необходимость в существовании такого движения, как ИГ. Основной целью Талибана в Афганистане сегодня является восстановление эмирата в виде, в котором он существовал при Мулле Омаре с 1996 по 2001 год. В Пакистане Талибан хочет реализовать концепцию, которая, как они считают, стояла за самим созданием Пакистана в 1947 году: концепция исламского национального государства для мусульман на территории тогдашней Индии.

По имеющимся сведениям, в настоящее время имеет место открытый конфликт между Талибаном и ИГХ, в особенности в восточном Афганистане. Выпущенный недавно документальный фильм Аль-Джазира - ИГИЛ и Талибан - обрисовывает динамику, оказывающую влияние на отношения между Талибаном и ИгХ. ${ }^{12}$ В одной из сцен, к примеру, казнят десять человек за то, что они сотрудничали с Талибаном. В документальном фильме также показано, как Талибан в Афганистане не видит никакой необходимости в существовании такого движения, как ИГ, и как ИГ утверждает, что Талибан находится в кармане пакистанских разведывательных служб и поэтому не ведет настоящую борьбу за ислам. Враждебность между ИГХ и Талибаном так же видна в пропагандистских материалах ИГ. В одном интервью губернатор Хорасана описывает Талибан как националистическое движение, которое не только находится в кармане пакистанской разведки, но и находит вдохновение в племенной традиции, а не в законах Бога. ${ }^{13}$

12 Jamie Doran and Najibullah Quraishi, "ISIL and the Taliban," Al-Jazeera, November 1, 2015, http://www.aljazeera.com/programmes/specialseries/2015/11/islamic-stateisil-taliban-afghanistan-151101074041755.html.

13 "Interview with the Wali of Khurasan," p. 49. 
Руководство ИГХ состоит из перебежчиков, т.е. бывших лидеров Талибана (хотя и не из самых верхних эшелонов иерархии). Попросту говоря, это те, кто были недовольными целостным руководством пакистанского Талибана и поэтому решили отколоться. Вот почему, у них персональная подоплека в действиях против их бывших соратников. Однако, движения, составляющие Талибан, остаются сильнее, чем ИГХ, и предварительные наблюдения показывают, что с движением ИГХ связаны где-то около 1000 человек (в основном в Нангархаре в Афганистане и в племенных территориях в Пакистане). ${ }^{14}$ Поэтому ИГХ в настоящий момент не является сильным игроком, но это определенно может измениться, если большее число местных движений перейдет под черные знамена.

Рассматривая движения Талибан в Афганистане и в Пакистане, можно сказать, что ни одно из них не оторвалось от культуры, в которой они возникли и в которой они укоренились. Наоборот, они переняли те социальные структуры, в которых лидерство и лояльность зависят от семейных и племенных связей и от способности лидера обеспечить безопасность для своих пехотинцев и членов их семей. По той же причине, отношения между таким иностранным движением, как ИдУ и Талибаном никогда не были особенно близкими, и весьма вероятно, что культурные различия являются слишком сильными между таким движением, как ИГ с его транснациональным этосом, и Талибаном с его традиционным обществом и специфически племенными иерархиями, и при котором личные отношения с лидерами очень важны.

Существуют значительные внутренние отличия и конфликты между Талибаном (как афганским, так и пакистанским), с одной стороны, и ИГХ, с другой, в которых соперничающие движения бросают ИГХ вызов в борьбе за влияние. Кроме того, ИГ приходит с новой идеологией, которая не имела до этого никакой поддержки в Пакистане и Афганистане. Вызов, перед которым стоит ИГХ, это, во-первых, заставить все существующие вооруженные движения признать аль-Багдади в качестве халифа и фигуры мессии, и во-вторых, убедить существующие движения, что апокалипсис наступил и ИГ - это и есть армия с черными знаменами, описанная в мифологических предсказаниях.

\section{Как насчет Аль-Каиды?}

Отношения между ИГХ и Аль-Каидой в Афганистане и в Пакистане так же напряжены, как и отношения между ИГХ и Талибаном. Это можно увидеть в пропаганде ИГ, в которой Аль-Каида в Пакистане описывается как про-

14 Bill Roggio, "State Department Lists Islamic State's 'Khorasan Province' as Foreign Terrorist Organization," The Long War Journal, January 14, 2016, доступно на http://www.longwarjournal.org/archives/2016/01/state-department-lists-islamicstates-khorasan-province-as-foreign-terrorist-organization.php. 
должение пакистанской разведки, таким же образом, как и Талибан. ${ }^{15}$ Интересно отметить, что руководство Аль-Каиды было верно духовному лидеру Талибана с 2001 года. Усама бен Ладен соблюдал верность (баях), в которой он поклялся Мулле Омару, и лидер АК, Айман аль-Завахири подтвердил эту лояльность после смерти Усамы бен Ладена. Когда было объявлено о смерти Муллы Омара, аль-Завахири присягнул на верность его преемнику, Мулле Мансуру. Недавно, после того, как Мулла Мансур был убит американцами, региональные подразделения АК, т.е. АКАП, АКИМ и Фронт ан-Нусра сделали совместное заявление, в котором превозносили погибшего Эмира, и Завахири заявил о своей преданности новому лидеру Талибана, Хайбатулле Ахундзаде. Ни Талибан, ни Аль-Каида когда-либо признавали аль-Багдади законным халифом; наоборот, они сделали несколько заявлений, в которых подтвердили, что остаются верны своим собственным идеям.

Первые штаб-квартиры Аль-Каиды были в Афганистане и в Пакистане, и после 2001 года международное сообщество сосредоточило свои удары на организации, известной как Аль-Каида Центральная (АКЦ). АКЦ означала центральный руководящий и консультативный орган (шура), в котором принимались основные решения организации. Первоначальное ядро Аль-Каиды сейчас существенно уменьшилось, и некоторые наблюдатели указывают на то, что первоначальная АКЦ и шура не располагают прежней властью и движение стало намного децентрализованным, чем вначале. ${ }^{16}$ Однако, Аль-Каида никогда не уходила из этого региона, хотя пониженный интерес СМИ в Аль-Каиде и Афганистане/Пакистане может создавать такое впечатление.

Есть некоторые споры о влиянии Аль-Каиды в Афганистане сегодня. В октябре 2015 года США нанесли удар на лагерь Аль-Каиды в Кандагаре, и это посеяло некоторое сомнение относительно числа боевиков Аль-Каиды, оставшихся в Афганистане, которое перед этим было озвучено американской разведкой (по оценкам от 50 до 100 человек). ${ }^{17}$ Оказалось, что только в лагере в Кандагаре было более 150 активных боевиков АК. ${ }^{18}$ Кроме того, между 2007 и 2013 годами было зарегистрировано 338 нападений Аль-Каиды в 25 из 34 провинций Афганистана, и это спровоцировало вопрос,

15 "Interview with the Wali of Khurasan," p. 49.

16 Deb Riechmann, "Al-Qaida decentralized, but not necessarily weaker," Associated Press, June 1, 2014, доступно на http://bigstory.ap.org/article/al-qaida-haschanged-shape-it-weaker.

17 Eric Schmitt and David E. Sanger, "As U.S. Focuses on ISIS and the Taliban, AI Qaeda Reemerges," NY Times, December 29, 2015, доступно на www.nytimes.com/2015/ 12/30/us/politics/as-us-focuses-on-isis-and-the-taliban-al-qaeda-re-emerges.html.

18 Thomas Joscelyn and Bill Roggio, "US Military Admits Al-Qaeda is Stronger in Afghanistan than Previously Estimated," The Long War Journal, April 13, 2016, доступно на http://www.longwarjournal.org/archives/2016/04/us-military-admitsal-qaeda-is-stronger-in-afghanistan-than-previously-estimated.php. 
насколько достоверны официальные числа властей США. ${ }^{19}$ Однако, остается затруднительным дать точную численность Аль-Каиды, поскольку некоторое число движений периодически сотрудничает с Аль-Каидой и следует ли включать и их, зависит от охвата определения АК.

В сентябре 2014 в Пакистане была создана новая ветвь Аль-Каиды Аль-Каида на Индийском субконтиненте Аль-Каида Бар-и-Сагхир (АКИС). Айман аль-Завахири объявил о существовании АКИС, которая должна действовать в Пакистане, Индии, Бангладеш и Мьянме. Позже представитель АКИС подчеркнул, что главными целями АКИС являются борьба с американским присутствием, установление исламского права в Южной Азии, конец оккупации мусульманских стран и защита Афганистана под руководством ныне мертвого Муллы Омара. Когда пакистанская армия начала проведение военных операций в северном Вазиристане в племенных территориях Пакистана, похоже, части АКИС перешли в южный Афганистан (Кандагар и Хелманд), где они взяли под свой контроль некоторые районы совместно с Талибаном.

Что интересно относительно АКИС, это то, что это региональное движение (как и АКАП и АКИМ), которое стремится больше к местному влиянию и вербует своих сторонников среди местного населения. Раньше АК имела четко арабский этос (в основном египтяне, саудовцы, йеменцы и боевики из Ливии), но в последние годы она все более открыта к местным движениям. Некоторые аналитики даже считают, что учреждение АКИС было, в основном, осуществлено в ответ на усиление влияния ИГХ в регионе, движение также демонстрирует институционализацию развития, которое уже произошло. К примеру, еще в 1992 году было известно, что Аль-Каида проявляет активность в отношении мусульман в Мьянме, которые были перемещены воинствующими монахами. В частности, давние связи с АльКаидой имеет движение Махаз-е Ислами, и группы приверженцев Аль-Каиды есть в Мьянме, Пакистане и Афганистане.

До сих пор эта группировка не организовывала серьезные нападения, но она попала в свет юпитеров, когда взяла на себя ответственность за нападение на пакистанские корабли в Карачи, после чего группировка сделала заявление, что нападение было совершено в отместку за то, что американские и индийские силы проникли в пакистанский флот, нападение было на американцев и индийцев, а не на пакистанцев. С того времени несколько руководителей АКИС были уничтожены при ударах, нанесенных беспилотными летательными аппаратами.

\section{Халифат-джихадизм}

Талибан в Пакистане в первую очередь появился в ответ на военные операции пакистанской армии в племенных территориях, и в столице, Исламабаде, где Красная мечеть подверглась удару армии в 2007 году, после

19 Там же. 
того, как была обнаружена ее связь с терроризмом. По истечение времени пакистанский Талибан стал на сторону голосов, которые в пакистанском контексте утверждали, что Пакистан должен быть исламским государством (а не просто государством для мусульман). Ни в Пакистане, ни в Афганистане есть влиятельные группы, пропагандирующие учреждение транснационального исламского халифата. Наоборот, и первоначальный афганский Талибан и первоначальный пакистанский Талибан (и большинство других милиций, воюющих в Афганистане и в Пакистане) были строго националистическими движениями, воюющими за "настоящий Афганистан» и за «настоящий Пакистан», т.е. они боролись за то, чтобы определять идентичность, законы и администрацию государства.

ИГХ является транснациональным проектом, который местным движениям будет трудно принять. Однако, следующие несколько лет покажут, способно ли ИГХ распространять свою идеологическую концепцию. Любой их успех будет зависеть от того, насколько поляризованной станет война против Запада в следующие несколько лет. При более сильном военном ангажементе против ИГ в Ираке и в Сирии (и при возобновленном риске возобновления военного ангажемента в Афганистане, если ИГХ успеет закрепиться там), существует опасность, что апокалипсис может стать самоисполняющимся пророчеством и станет легче убеждать потенциальных рекрутов, что мусульманский мир должен объединиться перед лицом «общего врага».

Кроме самого транснационального проекта, отличительной чертой идеологии ИГ по сравнению с идеологиями существующих движений, которые приняли джихад в Пакистане и Афганистане, является амбиция создания халифата с насильственным джихадом. Хотя пропаганда Аль-Каиды тоже упоминает халифат и представляет его как нечто желаемое, создание халифата никогда не было основной движущей силой для Аль-Каиды и было всего лишь маргинальным элементом в заявлениях Усамы бен Ладена и его преемников. Идея вдохнуть новую жизнь в халифат не была особенно популярной среди вооруженных организаций в Афганистане и Пакистане. На самом деле, идея халифата была маргинальной концепцией, порожденной, в дополнение к Аль-Каиде, небольшим движением Хизб-ут-Тахрир в Пакистане, хотя эта группировка не поощряла насильственный джихад для достижения своих целей.

Следовательно, экспансионистский и насильственный халифат-джихадизм является новым проектом, который потребует некоторого времени для созревания в этом регионе. Кроме того, ИГ манипулирует идеей, что оно ведет наступательный джихад, что по мнению большинства военизированных движений в регионе может считаться законным только под руководством мусульманского лидера/командира. Даже такое движение, как Талибан в Пакистане, объявило свой джихад оборонительным, поскольку у них нет лидера, который по общепринятым интерпретациям джихада может сделать легитимной наступательно экспансионистскую 
войну. Поэтому поддержка наступательного джихада требует, чтобы альБагдади был признан халифом.

Поскольку Талибан является доминирующим военизированным движением в Афганистане и в Пакистане, имеют место существенные доктринальные отличия по вопросу, могут ли эти два движения объединиться и образовать единый фронт. Хотя ИГ черпает свои идеи в работах таких утвержденных салафистских авторитетов, как ибн Таймия, вдохновляется ранней ваххабитской традицией (прежде, чем она смешалась с саудовским роялизмом) и одним из главных исламистских идеологов, Сайидом Кутбом, но религиозные авторитеты ИГ находятся и среди нового поколения молодых идеологов (например 30-летний Турки аль-Бинали), которые сочетают ваххабизм с идеей халифата и насильственного джихада. ${ }^{20}$ Ирония здесь состоит в том, что хотя сейчас ИГ легитимизует восстановление халифата, частично мотивация движения проистекает из ваххабизма, который в историческом плане появился как критически настроенная к халифату идеология.

Что могут означать эти идеологические и теологические характеристики и насколько успешно ИГ сможет убедить вооруженные движения в этом регионе присягнуть на верность аль-Багдади, присоединиться к халифатджихадизму и нанести окончательный удар неверующим, покажут следующие несколько лет. Если ИГ не удастся убедить в этом вооруженные движения, которые действуют в данном регионе, тогда продолжатся внутренние войны против их оппонентов, как это сейчас происходит в конфликте между Талибаном и ИГ.

\section{6 авторе}

Мона Канвал Шейх, доктор, является старшим научным сотрудником в сфере международной безопасности в Датском институте международных исследований. Главная область ее компетентности - это вооруженные движения в Пакистане, точнее, движения связанные с пакистанским Талибаном. Предметом ее исследований является религиозное оправдание насилия и мобилизация для его применения. В более широком плане она работает в области исламских идеологий, связанных с Аль-Каидой, Хамасом и Братьями-мусульманами.

${ }^{20}$ Cole Bunzel, From Paper State to Caliphate: The Ideology of the Islamic State (Washington, D.C.: Center for Middle East Policy at Brookings, March 2015), доступно на http://www.brookings.edu/research/papers/2015/03/ideology-ofislamic-state. 